\title{
Sustainable development indicators for urban water systems: A case study evaluation of King William's Town, South Africa, and the applied indicators
}

\author{
G Morrison ${ }^{1}$, OS Fatoki ${ }^{2 \star}$, E Zinn ${ }^{1}$ and D Jacobsson ${ }^{1}$ \\ ${ }^{1}$ Water Environment Transport, Chalmers University, Goteborg 41296, Sweden \\ ${ }^{2}$ Department of Chemistry, University of Fort Hare, Alice 5700, South Africa
}

\begin{abstract}
In the light of the increasing pressures on the world's freshwater resources, changes in the present and future urban water systems are called for in order to achieve sustainable development. The transformation from unsustainable practices demands tools that measure progress and can warn of future trends. Sustainable development indicators (SDIs) have been suggested as tools for a number of fields, including the urban water sector. This case study applied 20 SDIs to an urban water system in King William's Town, a medium-sized city in the semi-arid, mostly underdeveloped Eastern Cape of South Africa. The main aims were twofold: To evaluate the sustainability of the urban water system, and to evaluate the individual factors according to criteria. A final working list of the 15 SDIs was found useful for the study area and was produced for use also in future studies.
\end{abstract}

\section{Introduction}

The increasing use of the world's freshwater resources, coupled with the acknowledged environmental deterioration and exhaustive use of limited resources and energy in a modern urbanised society, calls for changes in present and future urban water and wastewater systems. As a large part of the world's population still lacks access to safe drinking water and adequate sanitation, and as global urbanisation continues to increase, an expansion of these systems is necessary. For these reasons, it is important that policy-makers, engineers and the general public have proper information so that the current situation can be evaluated, trends identified, and ways can be found to a more sustainable future. Sustainable development indicators (SDIs) have been proposed in numerous fields as powerful tools for this work, and the urban water sector is no exception. Lundin et al. (1997) have compiled a number of proposed SDIs for this sector, and also evaluated them in a case study (Lundin et al., 1999) on Sweden's second largest city. This was in an urban environment of a developed country with little stress on its freshwater resources. A larger problem is facing developing countries with moderate or much stress on their freshwater resources, and therefore demands an additional study into the use of indicators in such areas. The aim of this study was to evaluate the use of 20 SDIs in urban water systems of King William's Town, South Africa.

The urban water system of King William's Town is currently not moving towards sustainability. Freshwater withdrawal from the Maden and Rooikrans Dams has passed acceptable levels and the future plan of inter-basin transfer is not believed to guarantee this resource beyond 2005. The treatment performance of the Schornville Sewage Treatment Works is poor and the removal percentage of phosphorus is decreasing. Coupled with increasing concentrations of $\mathrm{P}, \mathrm{N}$, and COD in the raw wastewater, the Buffalo River, already threatened by eutrophication and salinisation, is now receiving increased nutrient loads and oxygen demand. Certain

\footnotetext{
* To whom all correspondence should be addressed.

푱(040) 602-2011; fax (040) 653-1643; e-mail: Fatoki@ufh.ac.za

Received 12 June 2000; accepted in revised form 19 December 2000.
}

aspects have been improving though. The water consumption per capita per day has stabilised around $230 \mathrm{\ell} / \mathrm{cap} \cdot \mathrm{d}$ and is well above the WHO minimum levels.

\section{Introduction to indicators}

An urban society needs a number of infrastructural installations to function properly. The provision of safe drinking water and the removal and treatment of wastewater and storm water are prerequisites for a healthy population and the functioning city and urban water systems (UWSs) were initially designed in order to meet these objectives. More recently, global awareness and recognition of society's negative influence on the environment have grown and call for additional purposes and goals of an urban environment's subsystems, including its UWS. In addition to the original objectives, which mainly concerned human health, a modern water and wastewater system must consider energy efficiency, resource use, environmental effects, access to service, service quality and other aspects of sustainable development. The objectives of developing a UWS are to:

- preserve the quality of the raw water resource

- allow for sustainable use of the raw water sources

- supply the general population with safe drinking water in sufficient quantity

- supply the general population with adequate sanitation and

- reduce the use of limited resources and energy to within the levels of sustainability.

Indicators, in general, are pieces of information, which have a wider significance than their immediate meaning (Bakkes et al., 1994). An indicator is useful if it is of fundamental interest in decision-making, simplifies or summarises important properties, visualises phenomena of interest and quantifies and communicates relevant information (Gallopin, 1997). In addition to its essential quantifying function, further relevant functions include assessing conditions and trends (sometimes in relation to goals and targets), providing information for spatial comparisons, providing early 
TABLE 1

The 17 SDIs used in this case study (adapted from Lundin et al., 1997)

\begin{tabular}{|c|c|c|}
\hline Suggested indicator & Type & Suggested reference value \\
\hline Withdrawal\% & Pressure & $<100 \%$ of the raw water quantity \\
\hline Raw water quality & State & $\begin{array}{l}\text { All water should be drinkable according to Inter- } \\
\text { national or National Standards }\end{array}$ \\
\hline Protection & Response & All resources should be protected \\
\hline Water consumption & Driving force & Sufficiency \\
\hline Drinking water quality & State & $\%$ tap tests within WHO or National Standards \\
\hline Chemical and energy use for water quality & Efficiency & As efficient as possible \\
\hline Leakage, $\%$ & Efficiency & Low \\
\hline Reuse, $\%$ & Efficiency & High \\
\hline $\begin{array}{l}\text { Wastewater production } \\
\text { (litres per capita/day) }\end{array}$ & & Within STP capacity \\
\hline Combined sewers, $\%$ & & $<10 \%$ should be storm water \\
\hline $\begin{array}{l}\text { Treatment performance, } \\
\% \text { removal } \mathrm{BOD}, \mathrm{P} \text { and } \mathrm{N}\end{array}$ & Effectiveness & At least according to regulation \\
\hline Loads to receiving waters of $\mathrm{BOD}, \mathrm{P}$ and $\mathrm{N}$ & Pressure & Below critical load \\
\hline $\begin{array}{l}\text { Chemical and energy use for wastewater } \\
\text { treatment }\end{array}$ & Efficiency & As efficient as possible \\
\hline Resource use per removal of nutrients & Efficiency & As efficient as possible \\
\hline Recycling of nutrients, $\%$ & Effectiveness & $100 \%$ \\
\hline Quality of sludge & & Below International or National Standards \\
\hline Energy recovery & Efficiency & As high as possible \\
\hline
\end{tabular}

warning information and anticipating future conditions and trends.

Lundin et al. (1997; 1999) defined a sustainable UWS as "a one which over a long-time perspective provides required services while protecting human health and the environment, with a minimum use of scarce resources". With this definition in mind, the objectives of a modern UWS can be listed as: a reliable supply of safe water to all users for drinking, hygiene and household purposes, safe transport and treatment of waste, drainage of urban areas and recovery of resources for reuse or recycling. When developing and evaluating SDIs for UWSs, this definition and its consequent objectives may not be sufficient. Several other aspects arise that may be important for the assessment of existing systems and future solutions.

Lundin et al. (1997) initially proposed a list of 20 SDIs for urban water systems, by first categorising UWS in terms of four environmental and technical systems: freshwater resources, drinking water, wastewater and sewage sludge. Each system was represented by a limited number of dimensions broken down into indicators, selected on the basis of five criteria, which are:

- move towards or away from sustainability

- availability of data of sufficient quantity and quality to provide spatial and temporal trends

non-overlap of the indicators
- ready existence of goals and objectives for the quantities and qualities measured by the indicator and

- the ease of understanding the information to be relayed by the indicator.

The indicators were subsequently tested in a limited case study in Goteborg (Lundin et al., 1999), where 14 were demonstrated as useful in assessing the temporal variations of a UWS.

In this case study, 17 of the originally proposed 20 indicators (Table 1) were tested in an attempt to evaluate the sustainability of the UWS of the study area, and to evaluate the use of the individual indicators.

These SDIs were primarily developed for studies in developed countries in Western Europe and North America. As this study was to be performed for a developing country like South Africa, additional indicators were believed to be necessary to cover the additional developmental aspects present. The 134 indicators by the UNCSD Working List of Indicators of Sustainable Development (UNCSD, 1999) were reviewed as to which may have developmental relevance without overlapping the other 17 proposed indicators for urban water systems. Two indicators were chosen from the Working. These are, access to drinking water and access to sanitation, respectively.

Another indicator chosen for this study is the economic indicator. 
The King Williams Town municipality serves people of different socio-economic groups including the poor, rural settlements. Affordability of the system both to the utility and to the consumers needed to be evaluated.

\section{Introduction to the case study}

\section{The study area}

King William's Town (KWT) is in the Eastern Cape Province of South Africa (Fig. 1). The transitional local council (TLC) of the town was established in 1994. It includes the previously independent municipalities of KWT, Bisho, and Ginsberg, as well as the four towns of Zwelitsha, Phakamisa, Illitha and Dimbaza. The rural village of Tyutyu has been part of the TLC since 1995, while other rural villages within the area have elected not to be included. A report prepared by Setplan (1997) for the KWT TLC estimated the population at some 150000 . The TLC includes an estimated 27 535 households, of which some 10730 live in shack houses (Palmer Development Group, 1998). The population is mostly poor and expected to grow fairly rapidly at approximately $3 \%$ per year. The economy of the area is small and only a modest rate (2\%) of economic growth is expected within the next 10 years (Palmer Development Group, 1998).

The four dams, Maden, Rooikrans, Laing and Bridle Drift (Fig. 2) are the raw water sources for towns in the Buffalo River Catchment area. Maden was meant to supply KWT and Rooikrans was meant to supply Zwelitsha together with Laing Dam. Bridle Drift Dam supplies Mdantsane and East London (O'Keeffe et al., 1996). The KWT TLC is currently served by five existing sewage treatment plants (STPs) located at Bisho, Breidbach, Schornville, Zwelitsha and Illitha, respectively but the two main STPs are the Schornville and Breidbach STPs (Fig. 3).

\section{Application of the indicators to the case study}

The SDIs enumerated above were applied to:

- the freshwater resources

- the drinking water and

- the wastewater systems

- development

respectively in the catchment area.

\section{Freshwater resources}

The freshwater resources within the catchment area of KWT were assessed and quantified. Three SDIs - withdrawal, raw water quality and protection were applied to assess the sustainability of the system on this point:

\section{Withdrawal}

The withdrawal indicator is calculated by dividing the annual freshwater withdrawal by the annual available amount and was applied to the freshwater system in the TLC. It shows whether or not the withdrawal is at an acceptable level, and if future shortages are to be expected. Therefore, it is a sensitive SDI and would indicate an early warning. High quality data are usually easy to obtain on withdrawal volumes, as waterworks measure these, but

\begin{tabular}{|c|c|c|}
\hline \multicolumn{3}{|c|}{$\begin{array}{l}\text { TABLE } 2 \\
\text { Three additional indicators used in the case study }\end{array}$} \\
\hline Suggested indicator & Type & $\begin{array}{l}\text { Suggested } \\
\text { reference } \\
\text { value }\end{array}$ \\
\hline Access to safe drinking water & State & $100 \%$ \\
\hline Access to adequate sanitation & State & $100 \%$ \\
\hline Affordability of services & State & $100 \%$ \\
\hline
\end{tabular}

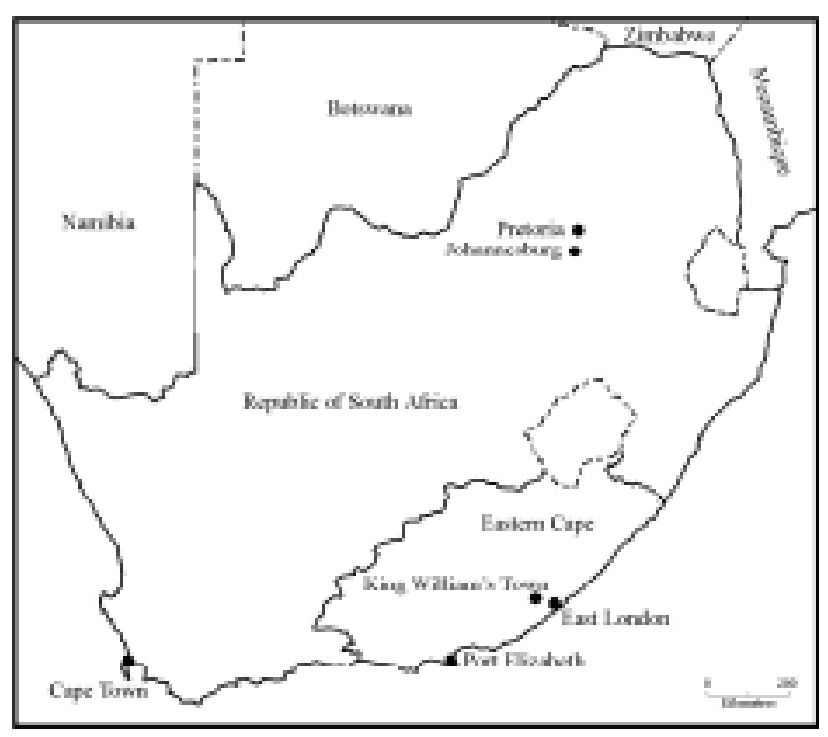

Figure 1

Map of South Africa and the location of the study area

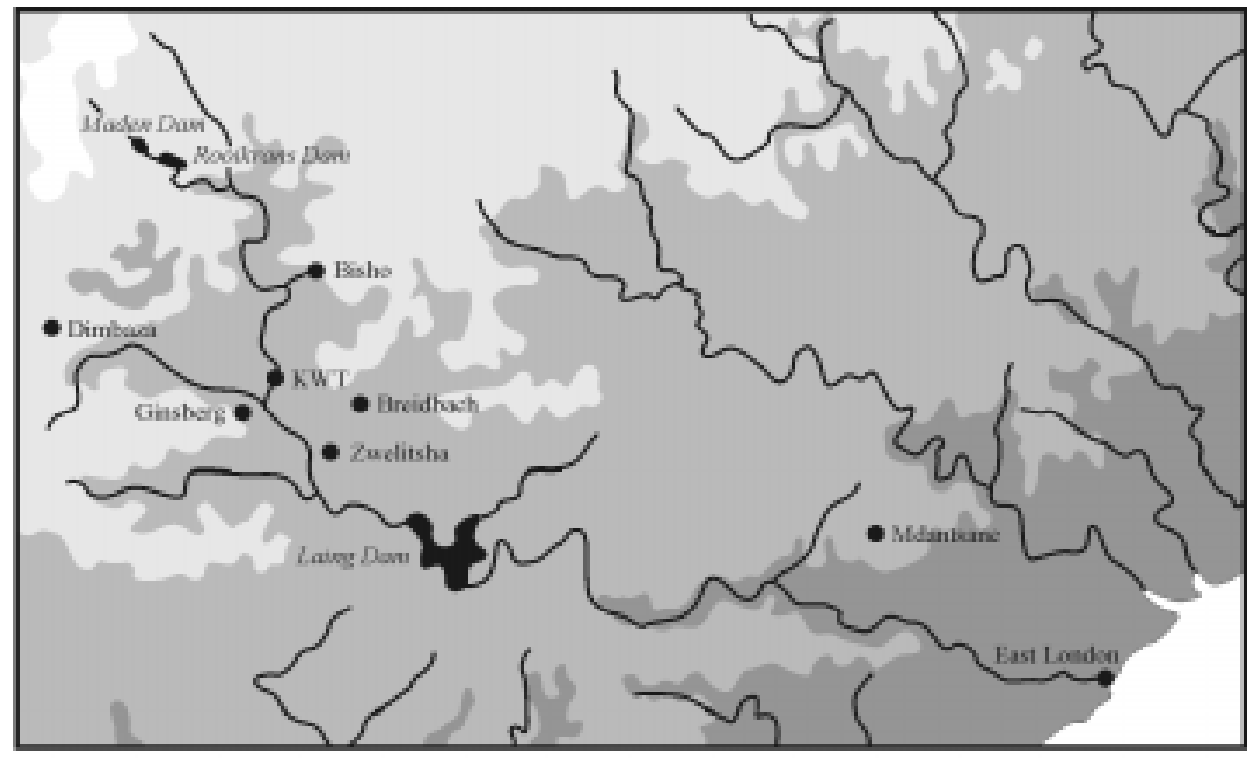

Figure 2

Map showing the dams of the TLC 


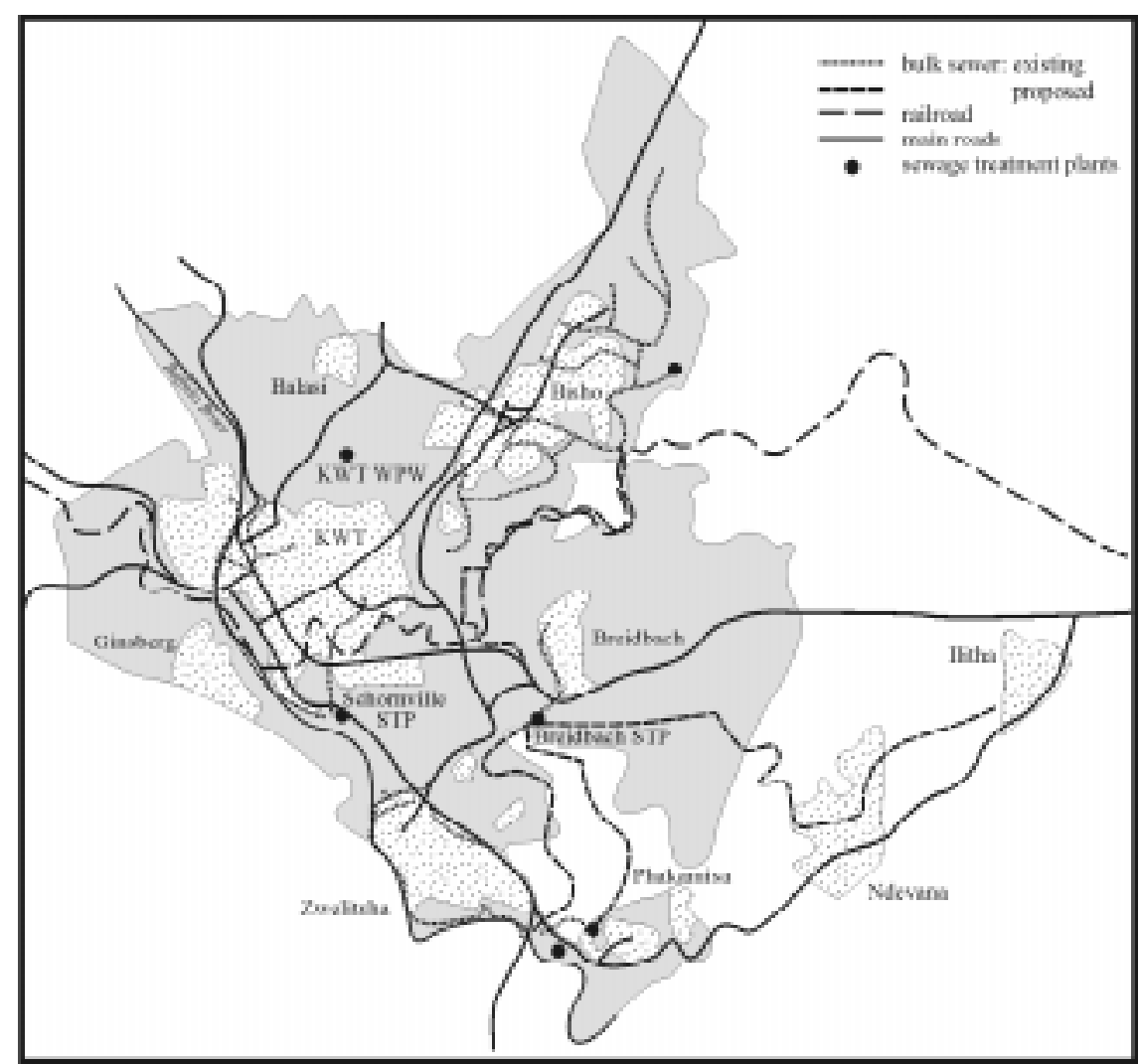

Figure 3

Map showing existing sewage treatment plants in the TLC (STP = sewage treatment plant; WPW = water purification works)

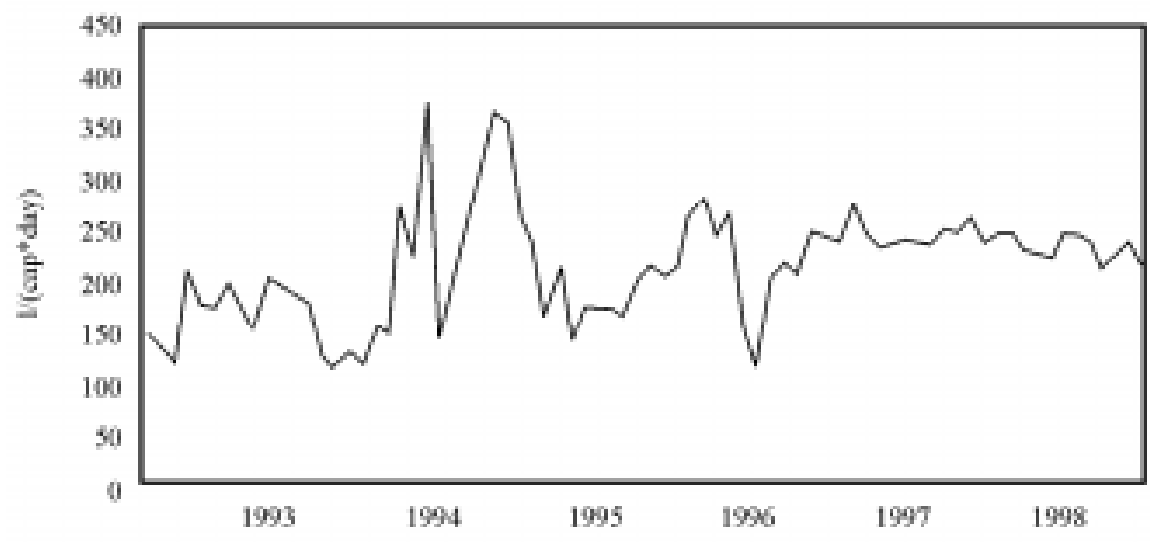

Figure 4

Total freshwater withdrawal as compared to estimated annual amount

Maden and Rooikrans Dam where data were available. Estimation of the annual available volume of raw water in Maden and Rooikrans Dams put it at a total of 3.1 $\mathrm{x} 10^{6} \mathrm{~m}^{3}$ (Gibb Africa, 1999). Previously, water was taken directly from both dams, but in 1995 to 1996 the pipes from Maden Dam were stolen and have not been replaced yet. Fortunately, Maden Dam is situated upstream of the Rooikrans, and the overflow from the former is collected by the latter before being piped to the KWTPurification Works. As the two dams are now working in series, the total withdrawal volume has been allocated. The collected data show that the withdrawal volume increased by $50 \%$ between $1993\left(2 \times 10^{6} \mathrm{~m}^{3}\right)$ and $1998\left(3 \times 10^{6} \mathrm{~m}^{3}\right)$ (Fig. 4).

The reference value for this indicator is that the withdrawal should be $<100 \%$ of the raw water quantity. The 1998 withdrawal equals approximately $100 \%$ of the total annual volume. Thus, the possibility of water shortages is clearly apparent. The engineering section considers the problem to be "a lack of pipes". Future plans include reconnecting the two dams with pipes (reducing loss due to infiltration and evaporation) and a further interconnecting of dams, such as the large Wiggleswade Dam north of Bisho. This, it is believed, will cover the future raw water needs of the TLC, but presently this is not the case. The current trend is moving not towards sustainability and future increases in water demand must be avoided. This indicator has been found useful for the system and it shows that future shortages should be expected if care is not taken. Several methods of reducing the consumption of water may be suggested such as installing waterefficient taps and toilets in new buildings (and the new RDP buildings), reusing grey water where applicable and educating the public on methods of saving water.

\section{Raw water quality}

This indicator is essential for the sustainable future of freshwater eco-

they need to be complemented with data from other consumers, e.g. irrigated agriculture and industries. Only estimations are possible for the available volumes of surface and groundwater. Data between areas vary depending on climate, population, economic development and seasonal variations. The withdrawal indicator also relates to population and population growth, the future demands for agriculture and industry and ecosystem health. An indicator should be total withdrawal compared to available amount but the latter is difficult to obtain.

The Maden and Rooikrans Dams supply three areas in the Transition Local Council (TLC) - KWT, Ginsberg and Breidbach via the KWT Purification Works. The indicator was applied to the systems, as well as for human health. This indicator also gives information on other activities that might affect the raw water source, e.g. point sources of municipal discharges, industrial discharges, and waste facilities, non-point sources such as agricultural and urban runoff and landfills. It also indicates the amount of treatment that is necessary to produce drinking water of acceptable quality that may affect the cost of energy and chemicals. For larger supplies of water, the quality is usually measured routinely.

The two dams are currently monitored by different authorities: the Rooikrans Dam falls under the jurisdiction of Department of Water Affairs and Forestry (DWAF), while the Maden Dam is 
monitored by the TLC. DWAF currently measures 16 parameters to establish raw water quality of the Rooikrans Dam. The reference value for this indicator is the International or National Standards for raw water quality. The water quality of the dam has been satisfactory for the entire period 1968 to1999. Only slight increases in the concentration of nitrate plus nitrite, orthophosphate and dissolved sulphate have been observed. Although dissolved sulphate most probably originates from long-distance sources of air pollution, the increased levels of nutrients may be due to the decreasing water levels in the dam. This may allow nutrients imbedded in the sediments to return to the water due to enhanced circulation. The natural exchange of nutrients between the sediments and water will also increase with the decreased volume of water. Although no data for the smaller Maden Dam were available, it is assumed to have the same quality of water. In favour of this assumption is the dam's proximity to the Rooikrans Dam, and the quality of water received by the waterworks. Thus for this indicator, the system seems to be moving towards sustainability.

Informing the general public of the raw water quality may be difficult, especially when coliform counts or phosphorus concentrations are given. A comparison with raw water targets should exist and would probably aid in the understanding of the situation. In this regard, the recently published Water Quality Guidelines of DWAF (1998) would be immensely useful in characterising raw water qualities.

\section{Protection}

A high degree of protected water sources ensures present and future freshwater quality, assuming that the protection is functioning well. The existence of a contingency plan indicates how prepared a community is for accidents and eventualities. Without protection and contingency plans, there will be an increasing risk of raw water pollution.

This indicator was tested on the water sources in the study area. There were no formal protections for the two dams, but both are located approximately $20 \mathrm{~km}$ from the main urban area of King William's Town, of which almost about $10 \mathrm{~km}$ is by gravel road, that is, a remote area. No further development of the area is planned and the Maden Dam is currently also used for trout fishing, while sailing is allowed on the Rooikrans. No evidence of an existing contingency plan for the eventuality of an accident that would pollute these sources beyond usage, was found, although, water is already drawn from Laing Dam in periods of drought. A "Disaster Committee", with members from the Department of Environmental Affairs and Tourism and from the Health Department of the TLC, among others, is responsible for action during times of crisis.

The lack of formal protection of the dams, as well as the nonexistence of a contingency plan in cases of emergency, are problems that do not favour sustainability and need immediate attention. The Disaster Committee on ground would be the appropriate body for drawing up a contingency plan.

As the population increases and development progresses, increasing volumes of water will have to be supplied for domestic and industrial purposes. It is therefore important that water is not wasted unnecessarily. Data are available from the local waterworks, and the distribution to different sectors (e.g. agriculture, industry, and leakage) is also of interest. As the consumption of drinking water affects the use of energy and resources, it is well linked to the general idea of sustainability. A suggested indicator is water use ( //cap.d) compared to target.

The KWT Water Purification Works is the main water purification works in the TLC and it receives raw water from the Maden and Rooikrans Dams. It supplies KWT, Breidbach and Ginsberg. The raw water is treated with lime, chlorine and aluminium sulphate. The water treatment plant reached $88 \%$ of its design capacity in March 1994, and peak water demands push the works into overload mode.

Consumption was calculated by dividing inflow values at the KWT Purification Works by the Setplan population estimation (Setplan, 1997), which was adjusted according to projected population increases. The water consumption (including industrial use and leakage) has increased from approximately $175 \mathrm{l} / \mathrm{cap} \cdot \mathrm{d}$ (mid 1993) to the peak of 1995 at 350 l/cap.d and now seems to be stabilising at around 230 to $240 \mathrm{\ell /cap} \cdot \mathrm{d}$ (Fig. 5). Deduction of the largest water-using industry using water from the Purification Works, King Tanning (2 $109 \mathrm{~m}^{3} /$ month, from O'Keeffe et al. (1996)), and leakage (20\%) results in a domestic consumption of just under 200 l/cap.d. Note though that the King Tanning consumption equals approximately less than $1 \%$ of the total water use.

The benchmark for this indicator is $25 \ell / d$. The average water consumption in the TLC is well in excess of the benchmark as well as the WHO minimum requirements (WHO, 2000). Thus, the system is moving towards sustainability on this point.

\section{Drinking-water quality}

In order to protect human health, the quality of drinking water is of the utmost importance. It should have, at the most, tolerable levels 


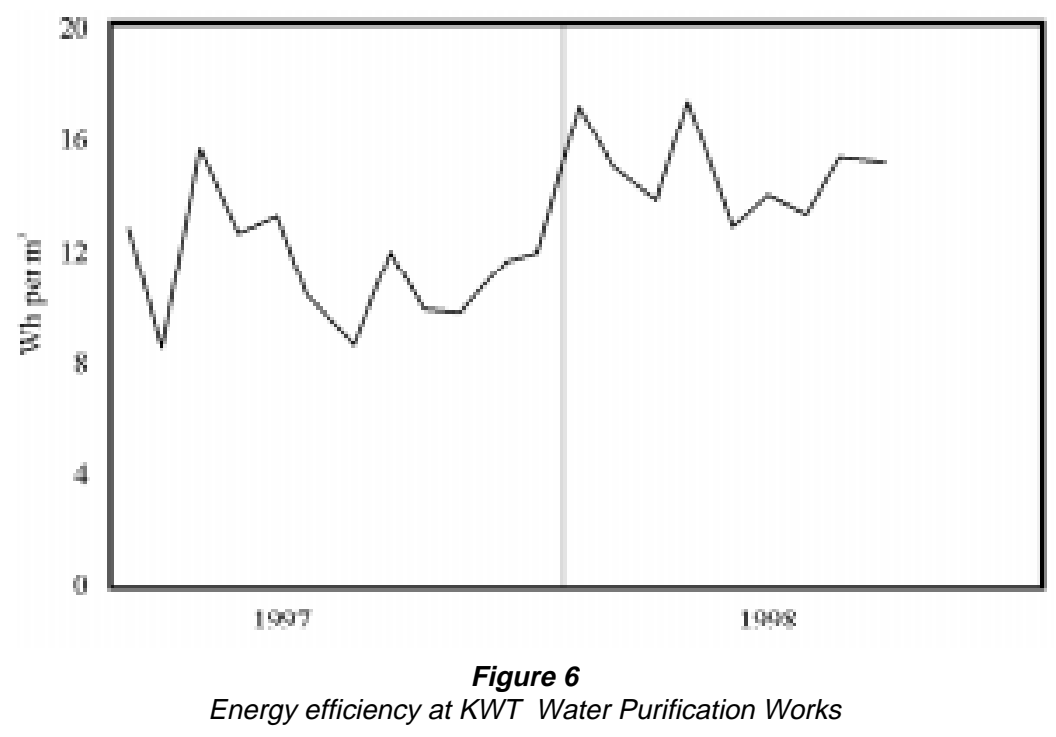

raw water quality and the degree of protection of freshwater resources affect this indicator. It, in turn, affects the quality of drinking water.

For the King William's Town TLC, data on the usage of chemicals at the waterworks have been obtained for the period Nov. 1996 to Dec. 1998. During this period, the withdrawal of raw water has been stable at around $3.1 \times 10^{3} \mathrm{~m}^{3} / \mathrm{y}$ or $225 \mathrm{l} / \mathrm{cap} \cdot \mathrm{d}$. The dosage of chlorine and lime has also been relatively stable during this period ( $2 \mathrm{mg} / \ell$ and $8 \mathrm{mg} / \ell$, respectively), while the dosage of $\mathrm{Al}_{2}(\mathrm{SO} 4)_{3}$ has increased from approximately $17 \mathrm{mg} / \ell$ to $20 \mathrm{mg} / \ell$. The total amount of chemicals used in 1997 and 1998, respectively were, $\mathrm{Al}_{2}(\mathrm{SO} 4)_{3}, 53 \mathrm{t}$ and $61 \mathrm{t}$, lime, $27 \mathrm{t}$ and $26 \mathrm{t}$ and chlorine, $5.6 \mathrm{t}$ and $5 \mathrm{t}$. As the raw water in the Maden and Rooikrans Dams is of relatively good quality, it is unsure if this increased dosage was necessary. Future efficiency improvements are to be expected, as

of bacteria or chemicals. Bulk drinking water quality is measured at the treatment works, but this may deteriorate before reaching the consumer due to corrosion or contamination. Factors such as leakage may cause a difference between measured drinking water quality at treatment and actual quality at the tap.

The TLC performs regular water quality tests through a consulting company - Pollution Control Technologies, East London, but the company feels reluctant to release the results to the public. However, the results of some analyses of nitrate and residual chlorine obtained for 1998 showed that the levels of nitrate are below the WHO recommendation of $45 \mathrm{mg} \mathrm{NO}_{3}^{-1 /}$ (Haglund and Norman, 1984). The concentrations of chlorine seem to occasionally reach inappropriately high levels. A measurement of the free chlorine in tap water at the Civic Centre in central KWT was $0.79 \mathrm{mg} / \mathrm{\ell}$. Compared to Swedish regulations of a maximum of $0.4 \mathrm{mg} / \mathrm{l}$ (VA-Verket, 1997) - this is high. Although this one measurement should not warrant unnecessary concern, it indicates the importance of making all measurements accessible to researchers and managers. Current research has indicated that chlorine acting with the assimilable organic carbon (AOC) or biodegradable dissolved organic carbon (BDOC) can form trihalomethanes in water treatment plants, and this may have mutagenic effects on human cells.

Generally, the drinking water quality in the King William's Town TLC is assumed to be good. It is said that there is never a problem with either coliforms or E.coli at the treatment works and that the turbidity in recent years has varied between 1 FTU and 5 FTU, but is usually $<2$. However, there is the need for current data to be made available to lend credence to this assumption. The indicator is useful in tracking changes in drinking water quality. Informing the public of the importance of high quality drinking water and relating the current situation to regulations may also increase concerns of its preservation and protection. The suggested reference value for this indicator is $100 \%$ tap tests within regulation. This information is not available for the system and, therefore, an indication towards sustainability can not be confirmed.

\section{Chemicals and energy use for drinking water treatment}

The sustainable use of chemicals and energy requires an efficient use of these, but not at the cost of drinking water quality. Increased efficiency also means decreased cost for the treatment works. The

the dosing equipment at the King William's Town WaterPurification Works is imprecise, making it difficult to optimise dosing according to need, but it is hoped that new equipment will be installed soon. Future studies into the required dosage with new equipment might allow for future decreases in the chemical usage at this plant, saving both money and resources.

Energy efficiency has increased since 1997, when consumption was approximately $12 \mathrm{Wh} / \mathrm{m}^{3}$. In 1998 , this reached approximately $15 \mathrm{Wh} / \mathrm{m}^{3}$ (Fig. 6). The current chemicals and energy use for water quality in the TLC is not efficient, and therefore not sustainable. An examination of the possible sharp increase of energy used over the past two years should also result in multiple efficiency improving recommendations that will move the operation of the system towards sustainability.

\section{Leakage}

Large volumes of water are lost due to leakage in pipes (VAVerket, 1997) and leads to increased pumping costs, loss of water (and revenue), loss of pressure and increased risks of contamination by bacteria and corrosion products (e.g., copper, iron and zinc). Large amounts enter the sewage pipes, diluting the sewage and decreasing the efficiency of the treatment process. Data on leakage are relatively easy to obtain in areas where water meters have been installed in households. Otherwise, the municipality or other organisations may have possibly made estimations, but these data should be viewed critically. The control of leakage not only decreases costs and increases revenue; it may also prove a vital way of increasing the water supply in 'dry' regions, without having to increase the withdrawal from scarce water sources. This indicator has a direct effect on the amounts of wastewater produced.

Water leakage for the TLC has been estimated at $20 \%$, which is also the estimate for Goteborg, Sweden (VA-Verket, 1997). The Palmer Development Group (1998) also confirmed this estimate of leakage for the TLC. As to whether this indicator is improving or not, sufficient information was not available to make any assertion.

\section{Reuse}

In areas approaching the limits of their freshwater resources, even wastewater must be seen as a resource. Therefore, reusing it becomes important in achieving sustainability. Industries can reuse their wastewater if necessary after treatment. Households 


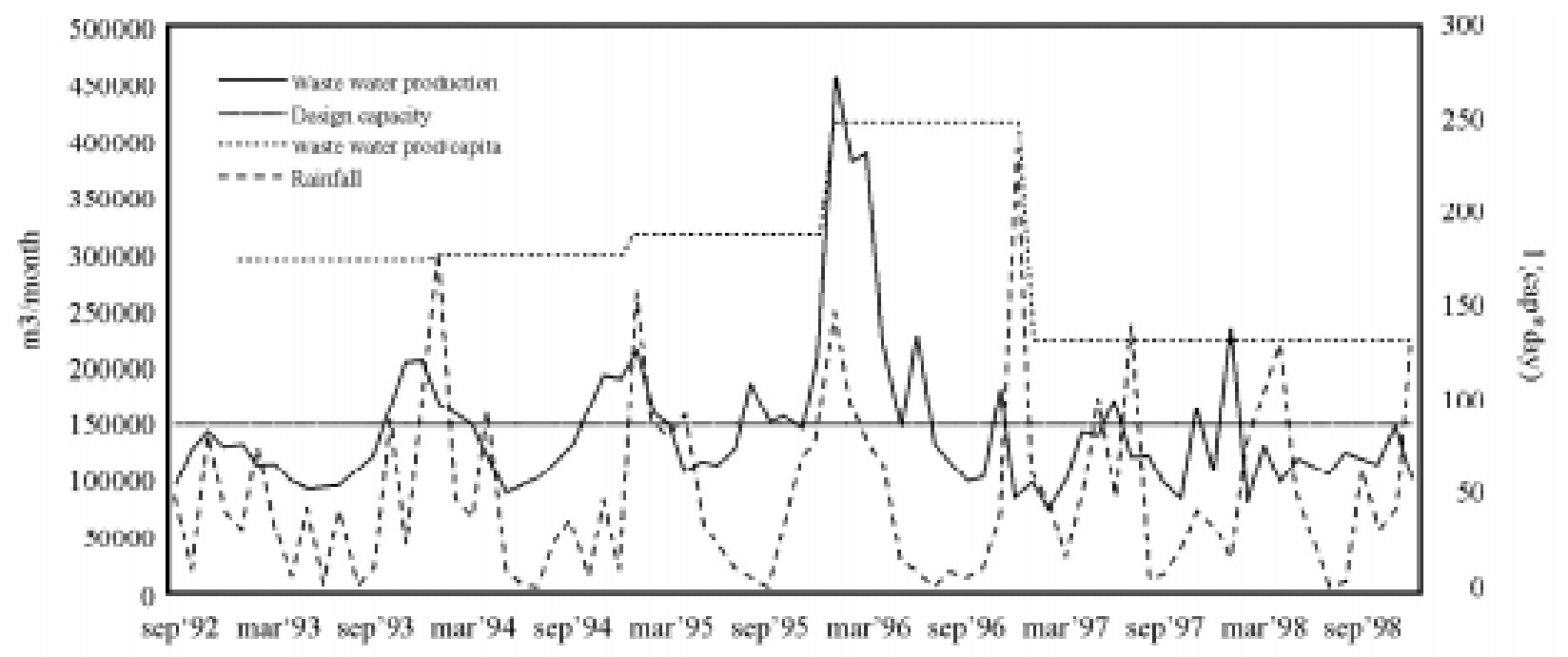

Figure 7

Wastewater production and the design capacity for the Schornville STP compared with rainfall data for KWT

can do the same by using grey water (sullage) and treated wastewater for non-potable purposes. Reusing wastewater for agricultural irrigation enables a cyclic use of not only water but also plant nutrients, although care should be taken so that it does not contain other components that may have detrimental effects on humans and/or have an adverse effect on environmental health.

In the King William's Town TLC, water is not being recycled and reused, but King Tanning and the KWT golf course receive approximately $20 \%$ of the effluent (prior phosphorus removal and chlorination) from Schornville Sewage Treatment Plant (STP) for irrigation purposes (Gibb Africa, 1999). Both received individually just under $0.2 \times 10^{6} \mathrm{~m}^{3} /$ year, for the period 1993 to 1996 , but since then the meters have been malfunctioning. Breidbach STP uses all the effluents for irrigation on sport fields. Generally, as far as this indicator is concerned for drinking water, the system is not moving towards sustainability.

\section{Wastewater}

\section{Wastewater production}

Increased production of wastewater can be caused by an increase in water usage or increased leakage of infiltration water and stormwater. This may have a number of detrimental effects: untreated water may be released into the environment due to combined sewage overflows, sewage may be treated at decreased efficiency and the amount of chemicals and energy used for sewage treatment may increase. The minimisation of wastewater, i.e., only wastewater is treated, is therefore important for environmental sustainability.

The King William's Town area is currently served by five existing STPs located at Bisho, Breidbach, Schornville, Zwelitsha and Illitha, respectively. As some of the treatment were not designed to treat these volumes, or are nonfunctioning, untreated and or partially treated sewage is discharged into the Buffalo River and its tributary, the Yellowwoods River. These rivers discharge into the Laing Dam, the main drinking water supply for the large settlements of Zwelitsha, Illitha and Phakamisa.

The two main STPs in the TLC are the Schornville and the Breidbach Sewage Treatment Plants. The Schornville STP is the larger of the two and is located within KWT proper, in an area of the town called Schornville. Built in the 1960s, it initially only applied mechanical and biological filters (biofilter) treatment but was updated and expanded in the 1980s with a separate activated sludge treatment step. Today the intention is that $60 \%$ of all incoming raw sewage should pass through the more effective activated sludge treatment step with phosphorus removal through chemical coagulation (further on referred to as the new section of the treatment plant). The remaining $40 \%$ passes through the old section of the plant with traditional sedimentation tanks, a biological treatment step, a sludge digester tank as well as sand filters (Gibb Africa, 1999).

The wastewater production received at the Schronville STP has been fluctuating for the past six years with an extraordinary peak in 1996 (Fig. 7). The rainfall curve correlates with the curve for wastewater production which could be proof of leakage of rainwater into the STP. In 1996 the inflow volume to Schornville STP was $2.55 \times 10^{6} \mathrm{~m}^{3}$, equaling $250 \ell / \mathrm{cap} \cdot \mathrm{d}$. This volume decreased in to just under $1.5 \times 10^{6} \mathrm{~m}^{3}$ or 135 l/cap.d.

The Schornville STP is overloaded with its design capacity of only $4800 \mathrm{~m}^{3} / \mathrm{d}$. (Gibb Africa, 1999). For example in June 1996, the average daily load was $7875 \mathrm{~m}^{3} / \mathrm{d}$. This approach for the STP will not lead to sustainability.

The much smaller Breidbach STP, which uses a pond system, received during the period 1995 to 1997 approximately $0.2 \times 10^{6}$ $\mathrm{m}^{3} / \mathrm{a}$, equaling $90 \ell / \mathrm{d}$ and person connected. The oxidation pond is not capable of producing effluent that meets the Special Phosphate Standard, which applies to the Yellowwoods River; hence the effluent is irrigated. Although no effluent should flow from the works, periodic discharges occur due to runoff from the irrigated lands and due to pond seepage (Department of Public Works, 1994). The Breidbach STW received less than the design capacity of $800 \mathrm{~m}^{3} / \mathrm{d}$ or 0.3 million $\mathrm{m}^{3} / \mathrm{a}$ (Gibb Africa, 1999).

\section{Combined sewers}

Using a combined sewage system, where surface runoff from impermeable areas (i.e. pavement, etc.) is carried to the wastewater treatment plant, increases the volumes received at the STP during rains. It also dilutes the sewage, making the treatment process less efficient; causes combined sewer overflows (releasing raw sewage into the environment) and pollutes the sewage sludge, thus 


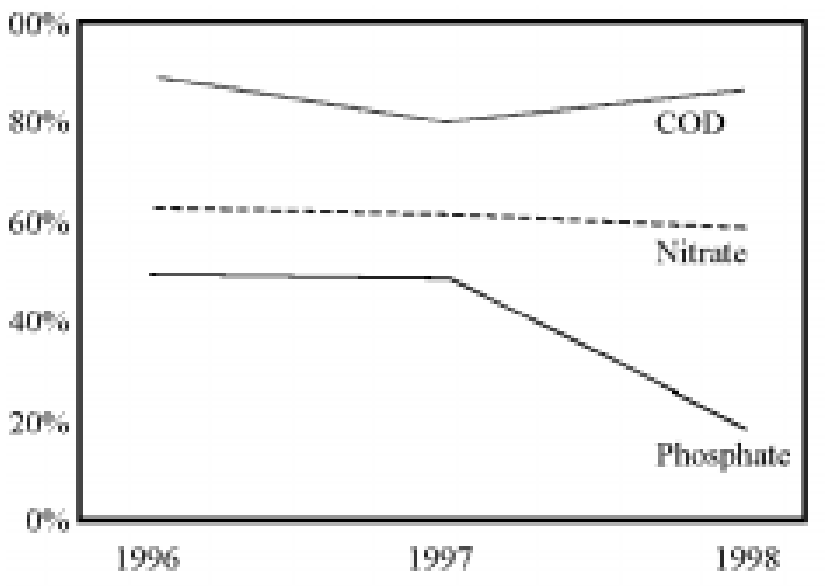

Figure 8

Treatment performance of the old plant at Schornville STP

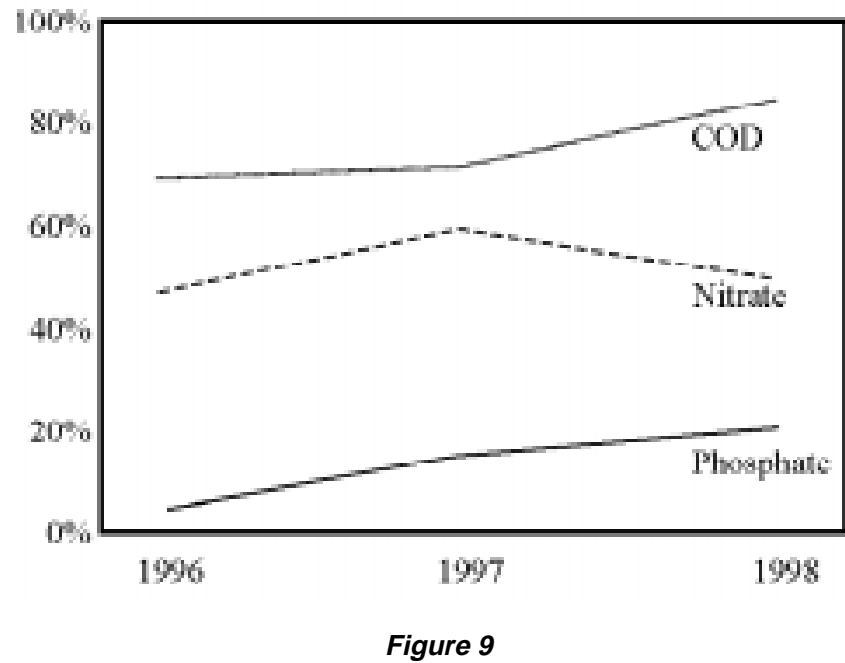

Treatment performance of the new plant at Schornville STP decreasing the possibility of recycling nutrients.

The standard in South Africa is separate systems, with one set of pipes for the domestic and industrial sewage, and another for surface runoff. King William's Town is no exception. One problem is that backyard tap (standpipe) drains, which are often built so that no rainwater can enter, are sabotaged. This may result in large volumes of rainwater entering the sewage system during heavy rains.

\section{Treatment performance for Schronville STP (\% removal of nutrients)}

Sewage treatment plants (STP) are built to treat collected wastewater. Their task is to reduce the amounts of pollutants in the wastewater before being released to the environment. The initial focus was on human health, but more recently the environmental health has become part of the agenda. The data on a STP's performance are important to measure the effectiveness of the treatment processes and these data are available for the larger Schornville STP.

Data for this SDI were as shown in Figs. 8 and 9. The removal of phosphorus was 50\% in 1996 and 1997, but dropped to 30\% in 1998 and for the first two months in 1999. The treatment performance for nitrogen which was conservatively estimated as the transformation of ammonia to nitrate, was $70 \%$ in 1996 and dropped to 50\% in 1998 and 1999 . The overall performance was better in the newer activated sludge plant than in the older biofilter.

The removal of substances causing chemical oxygen demand (COD) has been more effective in the new plant ( $82 \%$ to $91 \%$ ) than the old $(69 \%$ to $84 \%$ ) without any clear trend being obvious.

The transformation of ammonia $\mathrm{N}$ to nitrate seems to have functioned well during the period of this study, $58 \%$ to $71 \%$ in the old biofilter plant and $70 \%$ to $79 \%$ in the new activated sludge treatment system, resulting in an overall transformation ranging from $65 \%$ to $76 \%$. The removal of inorganic nitrogen has been somewhat less effective.

In the old plant, removal rates are around $50 \%$, while in the activated sludge plant removal rates are approximately $60 \%$.

In general, the overall treatment performance has been relatively stable for COD and decreased slightly for nitrogen, but decreased significantly for phosphorus. The decreased performance of the sewage plant in the removal of phosphorus may be due to the decreased use of ferric chloride (almost 50\% since 1996).

The reference value for this indicator is according to the National Standards which are $1.5 \mathrm{mg} \mathrm{NO}_{3}^{-}$as $\mathrm{N} / \ell, 1.0 \mathrm{mg} \mathrm{PO}_{4}^{3-}$ as $\mathrm{P} / \ell$ and $30 \mathrm{mg} / \ell \mathrm{COD}$, respectively, in the effluent that is discharged into the river. The effluent from sewage plant seemed not to meet these standards.

The decreased performance of the sewage plant, especially the biofilter system, would not lead to the sustainability of the plant.

\section{Loads to receiving waters}

To reach sustainability, the release of BOD (biological oxygen demand), phosphorus and nitrogen into the environment needs to be within what nature can cope with. Data for this indicator are easy to find for larger systems. This indicator serves as an early warning signal as increasing emissions of nutrients or oxygen-demanding substances will affect receiving waters at some point.

Data on loads to receiving Buffalo River from Schornville STP were as shown in Fig 10. The load discharged to the receiving waters was calculated for the Schornville STP by multiplying the measured concentrations in the outgoing effluents by $80 \%$ of the incoming volumes of wastewater, which is the estimated volume of treated wastewater being released into the Buffalo River (Gibb Africa, 1999).

Effluent levels of nitrate were exceeding acceptable limits for the years 1996 to 1999 . The highest annual average was in1998, when it was as high as $4.5 \mathrm{mg} / \ell$. Approximately $4000 \mathrm{~kg}$ of nitrate enters the Buffalo River every month from the Schornville STP plus an additional $700 \mathrm{~kg}$ of ammonia and this trend increased slightly in 1998. The load of nitrogen has increased as well, being around $1100 \mathrm{~kg} / \mathrm{month}$ for 1996 and 1997 and this increased sharply to about $2500 \mathrm{~kg} / \mathrm{month}$ in 1998 . This adds up to a total inorganic nitrogen load of around $1100 \mathrm{~kg} / \mathrm{month}$ for 1996 and 1997 and approximately $1500 \mathrm{~kg} / \mathrm{month}$ for 1998 .

Phosphorus effluent levels were at acceptable levels during 1996 and 1997, but these levels shot up above Special Standard regulations in 1998 to around $1.6 \mathrm{mg} / \ell$ and were increasing during the first two months for 1999 to around $2.3 \mathrm{mg} / \ell$. This also applies to the total P loads. In 1996 and 1997 this added up to approximately $70 \mathrm{~kg} / \mathrm{month}$, and jumped to over $150 \mathrm{~kg} / \mathrm{month}$ in 1998 .

The effluent COD levels have also been above the Special Standard limits of $30 \mathrm{mg} / \ell$ for the years 1996 to 1999 . In 1996 and 1997, the average effluent contained $6 \mathrm{t}$ of COD/month and this increased to a maximum of $15 \mathrm{t}$ in October 1999. This peak correlates with the peaks for $\mathrm{N}$ and $\mathrm{P}$.

The increased nutrient load from the Schornville STP to the Buffalo River would not lead to the sustainable use of the freshwater resource. 

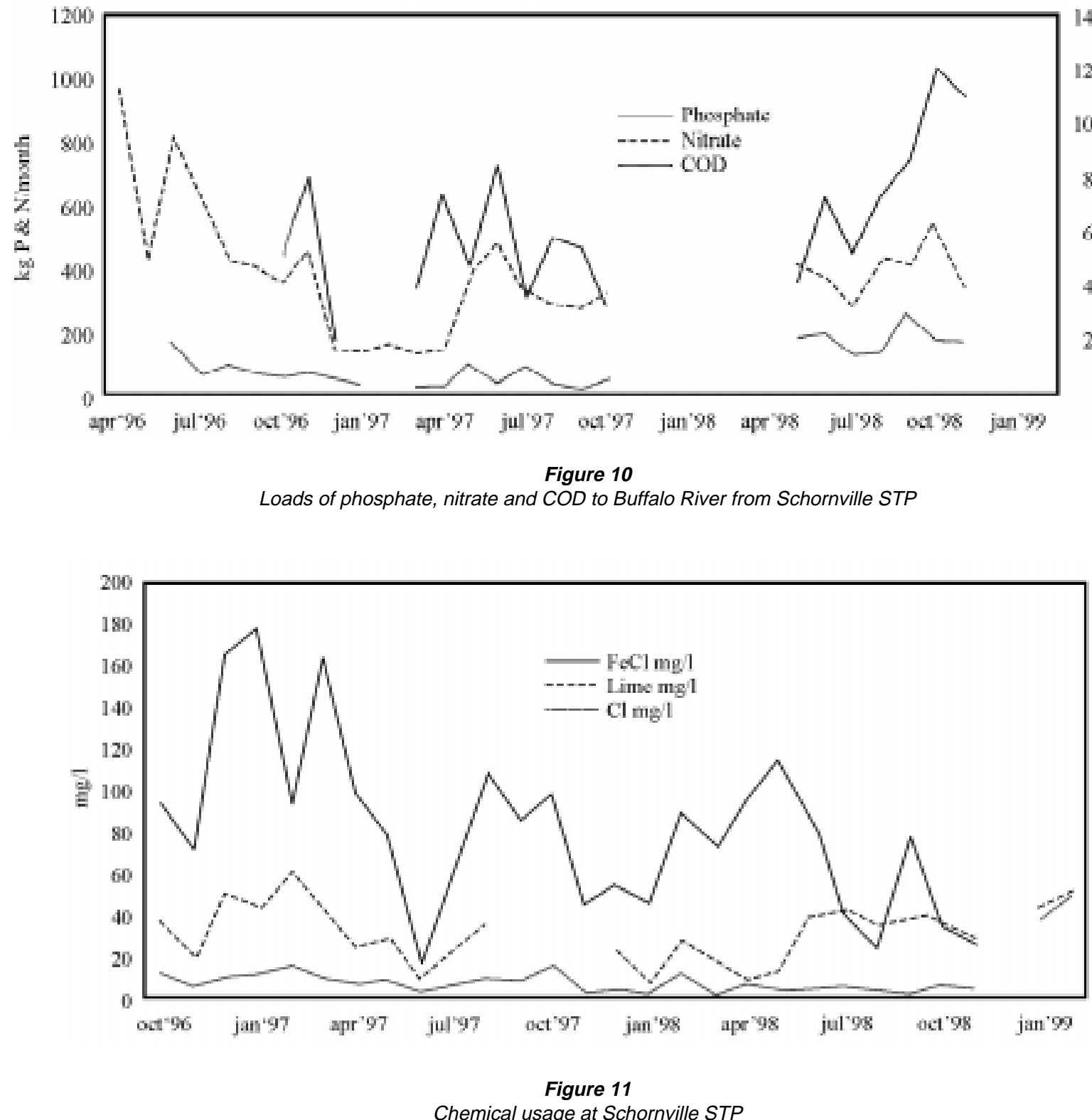

\section{Chemical usage for sewage sludge treatment}

This indicator is in line with the demands of an increased efficient usage of chemicals and energy in order to reach a sustainable operation of the sewage plant. The excessive dosage of certain chemicals (e.g. chlorine) may also have a detrimental effect on receiving waters and humans (chlorine can be converted to trihalomethane which is a suspect carcinogen). Data are available on energy and chemicals used in the treatment process at most sewage treatment plants.

At the Schornville STP, lime is first applied to the incoming effluent to adjust the $\mathrm{pH}$. 20\% of the flow is diverted after primary treatment to the King Tanning and the golf course, while $60 \%$ of the remaining flow (equaling $48 \%$ of the incoming flow) passes through activated sludge and phosphorus removal steps, where ferric chloride is added. Both internal flows (from the activated sludge system and the biofilter system, $80 \%$ of the total incoming flow) are finally treated with chlorine prior to release into Buffalo River.

The annual chemical usage at the sewage treatment plant was estimated by averaging the available monthly values of one year and multiplying by twelve. The use of chemicals has decreased considerably over the last few years. Ferric chloride has decreased from $73 \mathrm{t}$ in 1996 to $44 \mathrm{t}$ in 1998, lime from $47 \mathrm{t}$ in 1996 to $39 \mathrm{t}$ in 1998 and chlorine from $11 \mathrm{t}$ in 1996 to $5 \mathrm{t}$ in 1998. Considering the usage per volume of treated sewage in Fig. 11; the trends are the same. The dosage of $\mathrm{FeCl}_{3}$ has decreased from 113 to $64 \mathrm{mg} / \ell$, lime has decreased from just 35 to under $30 \mathrm{mg} / \ell$, and chlorine has decreased from 10 to around $5 \mathrm{mg} / \ell$. The decreased usage of ferric chloride has been unfortunate, as the concentrations of phosphorus (as well as nitrogen and COD) in raw wastewater have increased and the consequence has been the increased effluent concentrations and total loads to the Buffalo River. The decreased dosage of chlorine may also be inappropriate, as ammonia concentrations in the effluent have been increasing, ranging between $5 \mathrm{mg} / \ell$ to $20 \mathrm{mg} / \ell$ in 1998. As a rule of the thumb, $10 \mathrm{mg} \mathrm{Cl}_{2} / \mathrm{mg} \mathrm{NH}_{4}^{+}$(with a contact time of $30 \mathrm{~min}$. at 15 to $20^{\circ} \mathrm{C}$ ) should be applied in order to achieve sufficient sterilisation. The current dosage is considerably below this. Generally, the current usage of chemicals in the Schonville STP will not lead to sustainability of the treatment plant. 


\section{Resource use per removal of nutrients for the Schornville STP}

Measuring the efficiency of energy and natural resources used in the removal of nutrients from sewage is important, as the efficiency should be continuously improved as the technology allows. Data exist on the energy and chemicals used in the treatment process at most wastewater treatment plants and this can be compared to the amount of nutrients removed.

As previously described, $48 \%$ of the incoming sewage to Schornville is treated with $\mathrm{FeCl}_{3}$ at the activated sludge system to chemically coagulate and precipitate phosphorus. The efficiency of this process has been calculated by determining the degree of phosphorus removed (inflow and new plant effluent concentrations times $48 \%$ of incoming volumes) and comparing this with the amounts of $\mathrm{FeCl}_{3}$ applied. The efficiency of this removal varied considerably every year $-180 \mathrm{~kg} \mathrm{FeCl}_{3} / \mathrm{kg}$ P in $1996,131 \mathrm{~kg} \mathrm{FeCl}_{3} /$ $\mathrm{kg} \mathrm{P}$ in 1997 and $84 \mathrm{~kg} \mathrm{FeCl}_{3} / \mathrm{kg} \mathrm{P}$ in 1998. One reservation to the above calculation is that some of the phosphorus removed occurred in previous sedimentation steps without the aid of chemical coagulation. The increased efficiency must be viewed in the light of a decreased dosage of ferric chloride in a period of increasing influent and effluent levels of orthophosphate.

The benchmark for the indicator is $75 \%$ removal rate. The highest removal rate at Schornville is $50 \%$ of sludge containing 1.5 $\mathrm{P} \mathrm{mg} / \ell$ (a typical value for this study) with a dosage approximately $8 \mathrm{mg} \mathrm{FeCl} / \ell$ and an efficiency of around $12 \mathrm{~kg} \mathrm{FeCl}_{3}$ per kg P removal. In the light of these values, the efficiency at the Schronville sewage treatment plant must be viewed as poor and would not lead to sustainability.

\section{Recycling of nutrients}

The recycling of resources is a pillar of sustainable development and this naturally applies to water and wastewater as well. The recycling of sludge as fertiliser decreases the need for commercial fertiliser, which requires large amounts of mined phosphorus, a limited resource. Commercial fertiliser also contains nitrogen, and as it is only the ammonia and nitrate forms of nitrogen that plants can use, the fixing of atmospheric nitrogen to these forms for agriculture demands large inputs of energy. Increased usage of sludge as fertiliser will decrease the energy and resource used in agriculture if they meet quality standards, especially with heavy metals.

At Schornville STP, dried sludge is given away to farmers who are willing to collect it themselves. This results in erratic patterns of usage, as few have the possibility of transporting any considerable quantities. The percentage of sludge used for agricultural purposes in the study area was estimated at between 30 to $50 \%$, with the remainder being deposited at local dumpsites. Although this amount is considerable, future improvements are clearly possible. The indicator is useful for the system and the present practice would not lead to sustainability.

\section{Quality of sludge}

The use of sludge as a fertiliser is currently under fierce debate in many countries because of the risks coupled with its use. In many developed countries, the use is regulated.

To ensure the reuse of sludge as fertiliser without jeopardising human health, it must fulfil the public and legislative requirements. There are many aspects of interest when considering the quality of sewage sludge as fertiliser, but the main aspect of the danger and an important reason for reservations as to its use has been heavy metal contents of sludges. More recently in Europe, the possible contamination of parasites, bacteria and viruses led to increased concern (Albihn, 1999).

The detrimental effects of heavy metals and other chemical compounds are well documented (McLaughlin et al., 1999; McBride, 1998; Senesi et al., 1999). Several factors are currently being researched, such as availability, actual crop uptake, chronic effects on human health as well as other uncertainties.

Application of this indicator to the STP has revealed that quality tests, especially as regards to metal contents are not done on the sludges before they are given to farmers or before they are being deposited on the local dumpsites where there could be leaching to the environment. This approach would not lead to sustainability.

\section{Energy recovery}

Substantial amounts of energy are used for the collection and treatment of sewage and energy is also produced in the treatment process. Recovering some of it is in line with sustainable development. This can be done via biogas or heat pumps. These amounts of energy recovered by a plant should be recorded and should be made available. This, however, is an uncommon practice in South Africa and there are no such records at any of the sewage treatment plants in the King William's Town TLC. Data were not available to apply this indicator to the case study.

\section{Development}

The previous indicators were developed with the urban systems of Europe and the USA in mind. In a developing area such as this case study, other parameters must also be considered in order to evaluate the sustainability of the water and sewage treatment plants. The following ISDs - access to safe drinking water and access to sanitation - have been proposed by the UN Commission on Sustainable Development in their working list of Indicators of Sustainable Development (UNCSD, 1999). One other important ISD is the economic indicator that determines the cost or affordability of the services to the community in the TLC. This SDI is important because of the different socio-economic groups that are served by the TLC.

\section{Access to safe drinking water}

Safe drinking water is of the utmost importance in lowering the risk of faecal pollution and the frequency of associated diseases. "Safe" water does not contain biological and chemical agents at concentration levels directly detrimental to health. Access is defined as availability in the home or within a reasonable walking distance, although a more proper definition may be less than $200 \mathrm{~m}$ when in an urban area. An adequate amount of water should satisfy metabolic, hygienic and domestic requirements, and this is usually defined as $20 \ell / d$ (UNCSD, 1999). The World Health Organisation (2000) recommends a minimum of 15 to $20 \ell / d$ of clean water for consumption (drinking and food preparation) and sanitation (bathing, cleaning etc,).

About $5 \mathrm{~m}$. South African urban residents live more than 250 $m$ away from the nearest source of available water according to the most recent municipal survey of water provision. An additional $4.4 \mathrm{~m}$. people have access to communal standpipe at a distance of less than $250 \mathrm{~m}$ (Goldblatt, 1999). This is largely due to the predemocracy development policies. At present, The South African government has committed itself to ensuring that all people will have access to at least $25 \mathrm{l} / \mathrm{cap} \cdot \mathrm{d}$ of clean water which is the bench mark for this indicator (ANC, 1994; DWAF, 1994). 
The TLC services people of different socio-economic groups. Applying this indicator to the study area revealed variation in access to safe drinking water depending on the socio-economic group of people in the area. While access is about $100 \%$ in the rich areas like King Williams Town and Bisho, it varies between 90 and 95\% in the poor areas like Illitha, Zwelitsha and Dimbaza. In general, access to safe drinking water is between 95 to $97 \%$ in the study area (reference value for the indicator is $100 \%$ ).

Consumers in the rich areas pay full rate while those in poor informal settlements pay flat rates that are subsidised. While subsidisation of rates in the poor areas does not affect the quality of water supplied, it does however affect the quality of service and the quantity of water consumed. Many in the poor areas have access only to standpipes (communal taps) within walking distance from their homes while in the rich areas almost all consumers have in-house taps. At the study area, the average water consumption is above 50 l/cap·d(Palmer Development Group, 1998). The consumed average water per capita is well in excess of the WHO minimum limits of $20 \ell /$ cap $\cdot d$ (WHO, 2000). However, it must be stressed that water consumption is not uniform in the study area as people in the rich socio-economic group areas consume much more than those in the poor socio-economic group areas. This indicator is very useful and its application here shows that the system is moving towards sustainability in this regard.

\section{Access to adequate sanitation}

This indicator presents information that is useful for assessing sustainable development, especially as it relates to human health. The accessibility to adequate excreta disposal is fundamental to decrease faecal risk and the frequency of associated disease. This indicator can also provide evidence of inequity when studied from a geographic, social or economic point of view (UNCSD, 1999). This may prove to be especially useful in South Africa, due its previous political history. A sanitary facility is defined as a unit for disposal of human excreta, which isolates faeces from contact with people, animals, crops and water resources. Suitable facilities range from simple but protected pit latrines to flush toilets with sewerage. For any facility to be effective, it must be correctly constructed and properly maintained (UNCSD, 1999).

The SDI was applied to the case study. Sanitation in the study area is water borne and access to the system depends on the socioeconomic group of the consumers. While access is a most $100 \%$ in the rich areas of the TLC (e.g. King Williams Town and Bisho), it varies between 80 and $90 \%$ in the poor areas like Illitha, Zwelitsha and Dimbaza. In general, access to sanitation is between 92 and $95 \%$ in the study area (reference value for the indicator is $100 \%$ ). This indicator is useful and its application here shows that the system is moving towards sustainability. Cost of the service in the poor socio-economic group areas are again subsidised.

\section{Economic indicator}

Sustainability of the system needs to be assessed in terms of affordability both to the utility and to the consumers especially in a TLC that serves people from different socio-economic groups. The population of consumers currently served by the TLC includes the poor, rural settlements as well.

This indicator was applied to the study area. Services supplied are affordable to $100 \%$ of the people in the rich areas and they pay the full cost of services. Incidences of disconnection of services are rarely reported in these areas. In the poor areas, full cost of services is not affordable by a large number of people in the area and is therefore subsidised at a flat rate. Almost $100 \%$ of the population in the area can afford this flat rate. However, it is doubtful if this will be sustainable. The idea of paying a flat rate does not encourage people to minimise wastage of drinking water from leaking and broken pipes and it does not minimise cost of repairs and maintenance of sewer systems due to careless disposal of wastes. The TLC also can afford the cost of providing the services to the areas they serve.

This indicator is very useful for the study area. It is the SDI that will determine accessibility to services. The idea of subsidisation of costs of service to the poor areas makes it affordable to both the utility and the consumers but it is doubtful if this is sustainable.

\section{Suitability of indicators to the case study}

The majority of the 20 proposed indicators were developed for use in the developed countries of Europe. Whilst conducting this study in South Africa, it was evident that some of the basic conditions are different from the situation in Europe. An evaluation of the relevance and importance of each of the indicators will be of interest. A summary of the evaluation of the SDIs in terms of data availability, suitability, awareness of and score is given in Appendix 1. A brief discussion on this evaluation is given below:

\section{Freshwater resources}

Withdrawal (\%), as a SDI has a high relevance to the case study. The driving force is to save water since the demand is high and water is scarce. There is an awareness of problems related to high withdrawal and the SDI can predict a coming water shortage. Data are available for this SDI and it is easy to apply in the study area. It is a suitable SDI.

Raw water quality has a very high relevance in the study area since it has few water sources. There is awareness of this SDI in the TLC and raw water quality is good, but further downstream the problems are more severe. The reasons for this are leaking landfills on the riverbanks and untreated effluents entering the river. Some data are available for the SDI and can be applied. It is a suitable indicator.

A degree of protected sources as a SDI has relevance in the TLC. The driving force for this SDI is the prevention of pollution of the water sources. In the TLC, the water sources are not protected and the awareness for this SDI is not high. The SDI is not easily applicable to the study area and it is not a suitable indicator.

\section{Drinking water}

Water consumption (l/cap·d) SDI has a high relevance in the TLC that has an uneven consumption pattern for water between the rich and the poor. People in the rich socio-economic group consume a large quantity of the water that is available. The awareness of this SDI is high. The acknowledgement of the increasing population and hence increasing water demand and the current uneven water consumption pattern between the rich and the poor has set new goals for the TLC in order to achieve guaranteed water to all. Data are moderately available for the SDI and it is a suitable indicator.

Drinking water quality as a SDI could have relevance to the case study but measurements are not performed regularly on the drinking water quality and data are difficult to obtain. Little data were available for the SDI in the TLC and these were used to apply the indicator in the study area. The indicator is suitable.

The awareness of chemical and energy use for drinking water is low in the TLC. The dosage is done manually and adjusted a few times each day. However, data are readily available for the indicator in the TLC and it is a suitable indicator to use for the 
system.

Little is known about leakage in the system and data are not available for this SDI in the TLC. The awareness of the problem related to this SDI is high in the TLC but little is done because of the cost of repairing or replacing leaking water pipes. It is not a suitable indicator for the system.

The relevance and awareness of reuse as a SDI is high in the TLC. A good example is the fact that wastewater from the STPs in the study area is used to irrigate sport fields and a golf course, or sent to the industries. By increasing the reuse of water, a decrease of the effluent to recipients and a decrease of the withdrawal are achieved. Data are moderately available for the indicator in the TLC and it is suitable for the study area.

\section{Wastewater}

The awareness and relevance of wastewater production as a SDI is high in the TLC. Data are readily available for the SDI. The capacity of the major STP has already been exceeded. This SDI is useful because of population increase and new household connections through the extensive Reconstruction and Development Programme. Plans for the building of a new, larger-scale STP for the whole TLC is in progress. The indicator is suitable for the study area.

Combined sewers system is not a problem in the TLC as separate systems are built and therefore, this SDI does not have a high relevance to the TLC. It is not a suitable indicator for the system.

The awareness of the STP's treatment performance was not high in the TLC. However, data are moderately available for the SDI and it is a suitable indicator for the case study. A higher treatment performance is preferable for the environment. The Buffalo River that receives effluent from the Schornville STP, for example has a tendency towards eutrophication.

Loads to receiving waters as a SDI has great relevance to the study area. Reasons for this are that new houses are connected to the existing bulk network almost every day and the capacities of the STPs in the area have already been exceeded. Therefore, higher loads to the Buffalo River can be expected. The awareness of this SDI is high and data are moderately available. It is a suitable SDI for the case study.

The awareness of chemical and energy use for wastewater treatment is low in the TLC and the relevance is moderate. Data were readily available for the SDI. Dosage of chemicals at the Schornville STP is done manually. Therefore, efficiency might be low. The SDI is suitable for the study area.

Resource use per removal of nutrient as a SDI is very relevant to the study area but the awareness is low. This SDI is useful for protecting the environment and for saving money in terms of treatment cost. Moderate data were available and the SDI was suitable for the study area.

Recycling of nutrients was done to a small extent in the study area. The awareness of the SDI was low and little data are available. The relevance of the SDI is high to the study area. Sludge from the STP is now deposited on local dumpsites and leakage may occur which may also reach recipients. It is a suitable indicator for the system.

The relevance and importance of the sludge quality is high for the study area because of heavy metals concentrations in sludge and the presence of microbes. There is moderate awareness of this SDI in the TLC but no quality testing of the sludge was performed. It is a suitable SDI though, for the study area.

There were no facilities for energy recovery in the study area.
Though the SDI is relevant, the awareness for it is very low. Data were not available for the SDI in the TLC and it was not a suitable indicator for the study area.

Access to drinking water and to adequate sanitation are extremely important and are useful indicators for the study area. The awareness for each of these indicators is high in the TLC and they are suitable indicators for the system.

Economic indicator is also a SDI that has a high relevance to the study area because of the different socio-economic groups served by the TLC. The awareness for the indicator is high in the TLC and is a suitable indicator.

\section{Conclusion}

20 SDIs were tested for urban and wastewater systems in the King William's Town TLC and of these, 15 were found to be useful for the current situation in the study area and were recommended for future studies (Appendix 2). Some SDIs like raw water withdrawal, drinking water consumption, chemical use, wastewater production, treatment performance, loads to receiving, recycling of nutrients, access to drinking water, sanitation and economic indicator were easy to apply in the study area as data were readily available. Other SDIs, like drinking water quality, energy use, and quality of sludge were difficult to apply because data were not readily available. With this list of indicators, the sustainability and future trends of the water and wastewater systems in the TLC were assessed. The current situation for many indicators studied for the water and wastewater system in the TLC is not moving towards sustainability and some improvements are necessary in the operation of the systems to make them sustainable.

\section{Recommendation}

It is recommended that system managers in the TLC should obtain data on the following SDIs as indicated in Appendix 2 for future use to monitor sustainability of the systems in the TLC. These SDIs are: raw water withdrawal, raw water quality, drinking water consumption and drinking water and water reuse. Others include wastewater production, treatment performance, loads to receiving waters, chemicals and energy use for sewage treatment, resource use/removal of nutrients, recycling of nutrients, quality of sludge, access to drinking water, access to sanitation and cost or affordability of services.

\section{Acknowledgement}

The authors will like to thank SIDA for granting MFS scholarships to E Zinn and D Jacobsson.

\section{References}

AFRICAN NATIONAL CONGRESS (1994) The Reconstruction and Development Programme, Umanya Publications, Johannesburg.

ALBIHN A (1999) Kretslopp - mer smittsamt an hallbart? Forskning och Framsteg.

BAKKES JA, VAN DER BORN GJ, HELDER JC, SWART RJ, HOPE CW AND PARKER JDE (1994) An Overview of Environmental Indicators: State of the Art and Perspectives. Environmental Assessment Technical Reports, United Nations Environmental Programme, New York, USA.

DEPARTMENT OF WATER AFFAIRS AND FORESTRY (1994) Water Supply and Sanitation Policy White Paper: Water - An Indivisible National Asset, Government Printer, Pretoria.

DEPARTMENT OF WATER AFFAIRS AND FORESTRY (1998) Water 
Quality Guidelines. Quality of Domestic Water Supply Vol. 1. Assessment Guide.

DEPARTMENT OF PUBLIC WORKS (1994) Yellowwoods Regional Sewerage Scheme: Feasibility Study. Project No. 17107-3231.

GALLOPIN GC (1997) Indicators and their use: Information for decisionmaking. In: Moldan B, Billharz S and Matravers R (eds.) Sustainable Indicators. A report on the project on indicators of sustainable development, John Riley \& Sons, Chichester, England.

GIBB AFRICA (1999) Greater King William's Town Regional Sewerage Scheme, Initial Scoping Report, Job. No. J80220A, East London, South Africa.

GOLDBLATT M (1999) Assessing the effective demand for improved water supplies in informal settlements: A willingness to pay survey in Vlakfontein and Finetwon, Johannesburg. Geoforum 30 (1) 27 - 41.

HAGLUND K and NORMAN J (1984) Kvavet -Ett vattenvardsproblem. Miljoeffekter, utslapp,reningsmetoder, kostnader, (IVL) Swedish Environmental Research Institute, Stockholm.

LUNDIN M, MOLANDER S and MORRISON G M (1997) Indicators for the Development of Sustainable Water and Wastewater Systems. Sustainable Research Conference, Manchester.

LUNDIN M, MOLANDER S and MORRISON GM (1999) A set of indicators for the assessment of temporal variation in the sustainability of sanitary systems. Water Sci. Technol. 39 (5) 235 - 242.

McBRIDE MB (1998) Growing food crops on sludge-amended soils: Problems with the US Environmental Protection Agency method of estimating toxic metal transfer. Environ. Toxicol. \& Chem. 17 (11) $2274-2281$.

McLAUGHLIN MJ, PARKER DR and CLARKE JM (1999) Metals and micronutrients - Food safety issues. Field Crop. Res. 60 (1-2) 143- 163.

OECD (1998) Towards Sustainable Development, Environmental Indicators OECD, Paris.

O'KEEFFE JH, VAN GINKELCE, HUGHES DA, HILL TR and ASHTON PJ (1996) Buffalo River Project. A Situation Analysis of Water Quality in the Catchment of the Buffalo River, Eastern Cape, with Special Emphasis on the Impacts of Low Cost, High-Density Urban Development on Water Quality. Vol. 1 WRC Report No. 405/1/96 \& Vol. 2 (Appendices), WRC Report No. 405/2/96.

PALMER DEVELOPMENT GROUP(1998) Water Supply Services Model: Case Study of King William's Town. WRC Report No. KV110/98.

SENESI GS, BALDASSARRE G, SENESI N and RADINA B (1999) Trace element inputs into soils by anthropogenic activities and implications for human health. Chemosphere 39 (2) 343 - 377.

SETPLAN (1997) King William's Town TLC Framework Plan for KWT TLC by Setplan, East London.

UNCSD (1999) United Nations Sustainable Development - Indicators of Sustainable Development. http://www.un.org/esa/sustdev/isd.htm.

VA-VERKET GOTEBORG (1997) Arsberattelse 1996 Goteborg.

WHO (2000) The Management of Nutrition in Major Emergencies. Geneva.

\begin{tabular}{|c|c|c|c|c|}
\hline \multicolumn{5}{|c|}{$\begin{array}{c}\text { Appendix } 1 \\
\text { List of the SDIs indicating data availability, suitability, scores and levels of awareness of the indicators in the } \\
\text { study area }\end{array}$} \\
\hline SDI & Data availability & Awareness & Suitability & Score \\
\hline \multicolumn{5}{|c|}{ Category: Freshwater resources } \\
\hline Withdrawal & Readily available & High & Suitable & About $100 \%$ of total annual volume \\
\hline Raw water quality & Moderate availability & Moderate & Suitable & $\begin{array}{l}\text { Satisfactory according to National } \\
\text { Standards }\end{array}$ \\
\hline Protection & None & Low & Not suitable & No source is protected \\
\hline \multicolumn{5}{|l|}{ Category: Drinking Water } \\
\hline Water consumption & Moderate availability & High & suitable & Above WHO standard (20 l/cap·d) \\
\hline Drinking water quality & Not readily available & Moderate & Suitable & $\begin{array}{l}\% \text { of tap tests within WHO or National } \\
\text { regulation is not quantified }\end{array}$ \\
\hline $\begin{array}{l}\text { Chemical and energy use } \\
\text { for the drinking water }\end{array}$ & Readily available & Moderate & Suitable & $\begin{array}{l}\text { Chemical dosage not appropriate; } \\
\text { energy use is not efficient }\end{array}$ \\
\hline Leakage & Not readily available & High & Not suitable & No score \\
\hline Water reuse & Moderate & High & Suitable & Moderately reused \\
\hline \multicolumn{5}{|l|}{ Category: Wastewater } \\
\hline Wastewater production & Readily available & High & Suitable & Above capacity of the STP \\
\hline Combined sewers & Not available & High & Not suitable & Not used; no score \\
\hline Treatment performance & Readily available & Low & Suitable & Below National regulation \\
\hline Loads to receiving water & Moderate & High & Suitable & Above critical load to Buffalo River \\
\hline $\begin{array}{l}\text { Chemicals and energy use } \\
\text { for wastewater treatment }\end{array}$ & $\begin{array}{l}\text { Readily available } \\
\text { for chemical usage }\end{array}$ & Low & Suitable & Not efficient \\
\hline $\begin{array}{l}\text { Resource use per removal } \\
\text { of nutrient }\end{array}$ & Moderate & Low & Suitable & Not efficient \\
\hline
\end{tabular}




\begin{tabular}{|l|l|l|l|l|}
\hline SD1 & Data availability & Awareness & Suitability & Score \\
\hline Recycling of nutrients & Low & Low & Suitable & Much below $100 \%$ \\
\hline Quality of sludge & Not available & Low & Suitable & No score \\
\hline Energy recovery & Not available & Moderate & Not suitable & No score \\
\hline Category: Development & \multicolumn{5}{|l}{} \\
\hline $\begin{array}{l}\text { Access to clean drinking } \\
\text { water }\end{array}$ & Moderate & High & Suitable & $95-97 \%$ \\
\hline $\begin{array}{l}\text { Access to adequate } \\
\text { sanitation (water borne) }\end{array}$ & Moderate & High & Suitable & $92-95 \%$ \\
\hline \begin{tabular}{l} 
Affordability of services \\
\hline
\end{tabular} & Moderate & High & Suitable & $92-95 \%$ \\
\hline
\end{tabular}

\begin{tabular}{|c|c|c|}
\hline \multicolumn{3}{|c|}{$\begin{array}{c}\text { APPENDIX } 2 \\
\text { Recommended Working List of SDIs for King William's Town Urban Water System }\end{array}$} \\
\hline Indicator & Parameter(s) & Suggested reference value \\
\hline \multicolumn{3}{|c|}{ Category: Freshwater resources } \\
\hline Withdrawal & Total withdrawal compared to available amount & Less than 100 \\
\hline Raw water quality & $\begin{array}{l}\text { Concentrations of dissolved } \mathrm{Na}, \mathrm{N} \text { and coliform counts } \\
\text { compared to National Standards }\end{array}$ & Below National Standards \\
\hline \multicolumn{3}{|l|}{ Category: Drinking water } \\
\hline Water consumption & Water use $(\ell /$ cap $\cdot d)$ compared to WHO recommendation & WHO recommendations (20 l/cap·d) \\
\hline Drinking-water quality & $\%$ of tap tests with regulation & $100 \%$ \\
\hline $\begin{array}{l}\text { Chemical and energy use } \\
\text { for water supply }\end{array}$ & $\mathrm{mg} \mathrm{Cl} / \ell$ and $\mathrm{Wh} / \mathrm{m}^{3}$ & Increasing efficiency \\
\hline \multicolumn{3}{|l|}{ Category: Wastewater } \\
\hline Wastewater production & $\ell /$ cap $\cdot d$ & STP capacity \\
\hline Chemical and energy & $\mathrm{mg} \mathrm{Cl} / \ell, \mathrm{mg} \mathrm{FeCl} / \ell, \mathrm{Wh} / \mathrm{m}^{3}$ & Increasing efficiency \\
\hline Treatment performance & $\%$ removal of $\mathrm{P}, \mathrm{N}$, and $\mathrm{BOD}$ & According to National regulations \\
\hline $\begin{array}{l}\text { Resource use per removal } \\
\text { of nutrient }\end{array}$ & $\mathrm{Kg} \mathrm{FeCl}_{3} / \mathrm{kg} \mathrm{P}$ & Increasing efficiency \\
\hline Loads to receiving water & $\begin{array}{l}\% \text { loads of N, P, and Na compared to the critical load } \\
\text { for Buffalo River }\end{array}$ & Less than $100 \%$ \\
\hline Recycling of nutrients & $\%$ of nutrients recycled & Increasing towards $100 \%$ \\
\hline Quality of sludge & $\%$ of sludge quality tests within international regulations & $100 \%$ \\
\hline \multicolumn{3}{|l|}{ Category: Development } \\
\hline Access to drinking water & $\%$ of population with access within $200 \mathrm{~m}$ & $100 \%$ \\
\hline Access to sanitation & $\%$ of population with adequate sanitation & $100 \%$ \\
\hline Affordability & $\%$ of population that could afford the cost of service & $100 \%$ \\
\hline
\end{tabular}

